\title{
Transfer of Land Relations With Spatial Plan in The District of Pati
}

\author{
Ardika Budi Kusuma ${ }^{1}$ and Amin Purnawan²
}

Abstract. In this study, using the empirical jurisdiction, this research includes the identification law (common law) and research on the effectiveness of the law. Specifications of this research is descriptive, meaning from the results of this study will be described on the ruling, the legal system and analysis. Descriptive analytical research intended to describe of land rights transitional relationship with the spatial plan in Pati regency. The population in this research that all applicants for the use of a plot of land for specific uses in the district of Pati, while the sample is a subset or part of the population. The data used in this study are primary and secondary data. The data analysis used in this study is a qualitative analysis. The results of this research that the transfer of rights over land generally has nothing to do with the spatial plan, but related to the filing of the lands to be used as an industrial area, it needs to be made a rule of law or regulation that specifically applies to request transfer of rights over land will be used as an industrial area in Pati. During these provisions separately, as it is known that the transfer of land rights regulated in Act No. 5 of 1960 on Agrarian and Government Regulation No. 24 of 1997 on land Registration, which for the process require a long time with laws and regulations into one, then the parties will be easier to supervise and control the activities.

Keywords: Transfer of Land; Spatial Planning; Pati.

\section{Introduction}

The existence of the ground for human life is very important, since humans are born in the world until man dies in need of land. In order to realize an orderly field of land, the government enacted Act No. 5 of 1960 on Basic Regulation of Agrarian (later mentioned BAL). Land also memunyai very high economic value each year land prices always go up. The need for land for people from year to year is always increasing. The concept of land rights contained in the agrarian law, as follows:

- Rights on land that is of primary rights to land that can be owned or controlled directly by a person or legal entity who has a long time and are transferable to other persons or their heirs as Ownership Right (HM), Leasehold ( HGU), Right to Build (HGB), Right of Use (HP).

- Rights on land that is of secondary rights over land are temporary such as liens, rights of business for the results, the right to ride, and the right to hire on the farm.

To ensure legal certainty of ownership Rights to Land, the land should be registered as regulated in Article 19 paragraph (1) BAL states that "In order to ensure legal certainty

\footnotetext{
${ }^{1}$ Master of Notary's Student Sultan Agung Islamic University (UNISSULA) Semarang email : dikalownslow@gmail.com

${ }^{2}$ Lecturer of Faculty of Law UNISSULA
} 
of land ownership rights, the Government held land registration throughout the territory of the Republic of Indonesia in accordance with the provisions regulated by the Government ". Against the lands to be used as housing or industry should have to get a permit Spatial (ITR), but it also had to get permission from the land drying of District Land Office.

Article 1 (1) states that "Space is a container that includes land space, sea space and air space, including space in the earth as a whole region, where humans and other creatures live, operate, and maintain the continuity of life", whereas spatial as stipulated in Article 1 paragraph (2) UUPR, which "is a form of spatial structure and pattern of spaces".

Article 1 (1) states that "Space is a container that includes land space, sea space and air space, including space in the earth as a whole region, where humans and other creatures live, operate, and maintain the continuity of life", whereas spatial as stipulated in Article 1 paragraph (2) UUPR, which "is a form of spatial structure and pattern of spaces". Based spatial planning considerations for the existence of limited space and growing public understanding of the importance of spatial planning that is required of spatial planning transparent, effective, and participatory in order to create a safe space, a comfortable, productive, and sustainable. Spatial field development authority owned by the government of the District include the preparation and adoption of Spatial Planning District (RTRWK).

Structuring the effort to organize the land is the physical aspect of land use and management of the legal aspects of land tenure to support the implementation of the development. Efforts overall arrangement of land is done through two approaches implemented in complementary, ie physical approach structuring the use or utilization of land and legal aspects of the approach or the legality of land tenure arrangement. Government in carrying out its functions in managing spatial districts may carry out their duties well and were expected to consider the legislation in force, the authors are interested in conducting research research titled "Transfer Of Land Relations With Spatial Plan In The District Of Pati".

Based on the background as described above, then that will be examined in this study is what land rights transitional relationship with the spatial plan in District of Pati; and How spatial plan in Pati regency over the use of a plot of land for specific uses.

\section{Research Methods}

In this study, using the approach of the problem empirical jurisdiction. Empirical jurisdiction according to Dyah Susanti and Aan Efendi Ochtorina ie. Sociological research / empirical include research into the identification of law (common law) and research on the effectiveness of the law. ${ }^{3}$ Specifications of this research is descriptive analytical research, which means that these results will be depicted on the ruling, the legal system and analysis. In other word This research used social legal research approach, Tamahana stated that socio-legal studies are addressed to Law and Society Studies $^{4}$

\footnotetext{
${ }^{3}$ Dyah Ochtorina Susanti and A'an Efendi 2014 Penelitian Hukum (Legal Research) Sinar Grafika Jakarta p. 18.

${ }^{4}$ Anis Mashdurohatun, Redyanto Sidji, Gunarto and Mahmutarom, Factors Causing Banking Cyber Crime in Indonesian, International Journal of Economic Research, Volume 14 Number 15 2017, p.295
} 
The population in this research that all applicants for the use of a plot of land for specific uses in the district of Pati, while the sample is a subset or part of the population. ${ }^{5}$ The sample in this research is the application for the land for the use of a plot of land for the purpose tertentudi District of Pati Land Office.

Based approach to the problem in this study, the data will be used in this research are primary data and secondary data. Data collection activities conducted in order to obtain data and information, then the data will be used achieve the research objectives. ${ }^{6}$ Based approach, the method of data analysis used in this study is a qualitative analysis.

\section{Results And Discussion}

\subsection{Transfer of Rights to Land With Spatial Planning in District of Pati}

Land use or commonly referred to as land conversion is a change in the function of some or all of the land area of the original function (as planned) into another function had a negative impact on the environment and the potential of the land itself. Land use can also be interpreted as a change to other uses due to factors that broadly cover the need to meet the needs of a growing population numbers and increasing demands for a better quality of life. Land conversion is usually associated with the process of the development of the region, it can even be said that the land use is a consequence of the development of the region. Most of the land conversion is happening.

In general transitional land rights with the spatial plan is two (2) different things. If the land to be used as housing or to be made as an industrial area into a wet area, then it should not be drained, therefore, permit Spatial (ITR) and permit drying will not be lowered. However, in this case for the transition process is still running land rights in accordance with applicable regulations.

Minister of Agrarian and Spatial Planning / Head of National Land Agency issued Ministerial Regulation No. 5 of 2015 Agrarian on the Permit Area. Consideration of the issuance Ministerial Regulation No. 5 of 2015 is in order to acquire the land for the benefit of capital investment, the location permission is required before a company acquires or waiver of the ground of society. Location permit according to Article 1 (1) Ministerial Regulation No. 5 of 2015 is a license granted to the company to acquire land needed for investment which applies a transfer of rights and permission to use the land for purposes of investment business.

The role of spatial planning is basically to achieve optimal utilization of resources, and as much as possible avoid conflicts of resource utilization and prevent environmental damage and promote harmony. In general the relationship transfer of rights over land with the spatial planning in the District are not directly related, but the transfer of land rights to be used as an industrial area or residential area should get ITR, it is associated with the Spatial Plan, the applicant must followed by Spatial Plan that has been planned by the local government.

\footnotetext{
${ }^{5}$ Ibid p. 119

${ }^{6}$ W. Gulo 2002 Metodologi Penelitian Gramedia Widiasarana Indonesia Jakarta p. 112.
} 
During this time of licensing for the industry with the application for transfer of rights over land governed by laws and different regulations, because it is governed by laws and regulations are different, it often appears the problem, namely the discharge permit with the application of land rights can not go out together, so delayed. Therefore, the authors give special consideration that should permohoanan tenure, which will be used as industrial or residential area invitation legislation should be the one, so that if the licensing application is approved, the application for land rights also approved.

In a petition rules permitting the construction of housing in Pati regency, in general, the land is used by developers for residential development or housing, to make it easier to get permission construction of housing, then it should pay attention to the following matters: ${ }^{7}$

- Land is on track City Spatial Plan (RTRK)

- The land that will be managed as housing is on track City Spatial Plan (RTRK) with the aim that no difficulty in applying for a permit to use the land or land.

- Asking licensing at the Department of Public Works (MPW) and the Regional Development Planning Board (Bappeda)

- Developers apply for licenses at the Department of Public Works (MPW) and the Regional Development Planning Board (Bappeda).

- State Land Agency did check Certificate

- State Land Agency (BPN) through the District Land Office to check the certificate First we check whether the certificate is in conformity with the physical, ask the clerk to check whether the re-peg its boundary, is in conformity with the existing area of the certificate.

- Environmental Impact Assessment (EIA)

- Environmental Impact Assessment, applicable to the vast land for over 1 hectar, if the land area under 1 ha., then as his successor enough to permit UKL / UPL (environmental management efforts and the efforts to use the environment).

- Asking Licensing Office to the Integrated Licensing One Roof

- Apply for licenses to the Integrated Licensing Office One Roof to take care of Building Permit (IMB), in addition to submitting the IMB at the same time also take care of the applicant's attestation Housing site plan or also called Zoning.

Seeing the process is very long and exhausting and mind, it is essential to the process for application use of land for residential areas and industry needs to make its own laws and its invitation. The process of licensing application, as mentioned above, is very susceptible to corruption and collusion, this is because the bureaucratic process is very lengthy santa allows the developer or the developer will do practices of collusion by way of bribing officials and officers themselves can be guilty of corruption by the way taking bribes from developers.

If the laws and regulations specifically land or land that will be used as residential areas or industrial combined in the laws and regulations, it will be very easy supervision and minimize corruption and collusion, because the handling of the roof with the laws and regulations, then the developer or party applying for a permit.

\subsection{Spatial Plan in Pati Regency Piece Top Land Use For Specific Uses}

\footnotetext{
7 Interview with Mukhammad Head of Subsection Land Stewardship Specific Area and District Land Office Pati December 6 ${ }^{\text {th }} 2017$.
} 
Spatial plan Pati regency over the use of a plot of land for specific uses, which is usually submitted by the applicant is for the housing estates. District of Pati Government published Act No. 5 of 2011 on Spatial Planning Pati regency in 2010 and 2030, the aim is to steer development in Pati Regency by exploiting the region as efficient, barhasil order, harmonious, balanced and sustainable in order to improve Pati regency public welfare.

Change of use of agricultural land to non-agricultural indeed be a phenomena in the society and at the pace of development in all spheres of life. ${ }^{8}$ Changes of the soil functions that should be a function of agricultural land into industrial and residential land is something that deserves attention, because this situation gives a great influence on the lives and environment.

Changes in agricultural land use was not limited to just housing but for other activities outside of agriculture. Expansion of local industry, the addition of road networks and various other infrastructure as development demands will determine in the reduction of agricultural areas. ${ }^{9}$

According to Mukhammad Related to the issue of land use, stated that the importance of preserving agricultural land not only for food security but also for the preservation of the environment. Wetland is a land of the most stable compared to land for another goal. Soil leaching that occurs is very low, so is the level of erosion. If converted one hectare of irrigated rice in Java technically it should be built three hectares of irrigated land technically outside of Java with four or five years to become the new rice fields. ${ }^{10}$

Barriers or obstacles that occur in the change over the function of agricultural land to non-agricultural land is as follows: ${ }^{11}$

- Contradictory policies occurred because on the one hand the government attempted to prohibit the transfer of functions, but on the other hand the growth policy of industrial / manufacturing and other non-agricultural sectors would encourage the conversion of agricultural lands.

- Policy limited coverage. The regulations on the new imposed on firms / legal entity that will use the land and / or will change agricultural land to non-agricultural. Changes in land use from wetland to non-agricultural done individually untouched by these regulations. Whereas changes in land use that is done individually directly predicted quite extensive. Planning consistency constraints caused by the Spatial Plan (RTRW), followed by the mechanism of a location permit is the main instrument in the control to prevent technical conversion of irrigated land. In fact, many RTRW instead planned to convert technical irrigated rice land into nonagricultural.

\section{Closing}

\subsection{Conclusion}

Based on the results of research and discussion, it can be concluded as follows:

- Relations Transition Land Rights With Spatial Planning in District of Pati

\footnotetext{
${ }^{8}$ Ibid p. 91

${ }^{9}$ Maria Sri Wulani Sumardjono 2001 Kebijakan Pertanahan antara regulasi dan implementasi Kompas Jakarta p. 7.

${ }^{10}$ Interview with Mukhammad op.cit.

11 Ibid.
} 
In this study the transition of land rights with the spatial plan closely. In certain things in the use of land to be used as an industrial area and residential areas legislation invitation is set to be one, so as to save time labor costs and the mind, and also can reduce the leakage of funds and reduce collusion and corruption, the most important in terms of the Government may supervise the construction area of land used as a specific area can be done by one agency.

- Spatial Plan in the district of Pati piece Top Land Use For Specific Uses In the use of a plot of land for specific uses such as housing and industry, need to be evaluated. Evaluation required as consideration of the use and limitations as well as gather information that quite a lot of the land. Land suitability evaluation is basically related to the evaluation for purpose, ie the ability of the land, generally intended for a broader land use or as common as the use for residential, industrial and urban.

\subsection{Suggestion}

Based on the conclusions, as mentioned above, the authors are members of the following suggestions:

- To the Central Government, in order to make Laws Invitation governing the transfer of land rights to permit Spatial Planning on the use of a plot of land for specific uses, with review to save time, cost and effort of doing the maintenance, as well as to avoid collusion and corruption, and most importantly easier to control.

- To the community, especially developers or housing developers in order to take care of itself permit application for residential or residential permits to avoid collusion and corruption, so the local government performance can be optimized.

\section{Bibliography}

[1] Anis Mashdurohatun, Redyanto Sidji, Gunarto and Mahmutarom, Factors Causing Banking Cyber Crime in Indonesian, International Journal of Economic Research, Volume 14 Number 152017

[2] Dyah Ochtorina Susanti and A'an Efendi 2014 Penelitian Hukum (Legal Research) Sinar Grafika Jakarta.

[3] Maria Sri Wulani Sumardjono 2001 Kebijakan Pertanahan antara regulasi dan implementasi Kompas Jakarta.

[4] W. Gulo 2002 Metodologi Penelitian Gramedia Widiasarana Indonesia Jakarta.

[5] Interview with Mukhammad Head of Subsection Land Stewardship Specific Area and District Land Office Pati December $6^{\text {th }} 2017$. 